\title{
Historical and social aspects of solar eclipse occurrences
}

\author{
K. Tennakone* \\ 55 Amberville Road, North Andover, MA 01845, United States.
}

\begin{abstract}
The eclipses of the sun and moon are generally considered a part of astronomy irrelevant to other affairs of the society. The study reported here explores the contrary, showing that, eclipses of the sun have had a significant impact on society in terms of associated superstitions and counter arguments of rationality, regional conflicts, decision making by rulers, advancement of science and scientific politics. The history and social implications of eclipse prediction and eclipse expeditions are discussed highlighting situations relevant to Sri Lanka. Solar eclipse events, particularly important to Sri Lankan history, are examined in comparison with theoretically calculated dates of occurrence given in the NASA World Atlas of Eclipses. Results provide new insights into some historical events, especially significant in the context of Sri Lanka. Their chronology and possible interpretations are discussed. The information derived would be useful to historians for further analysis.
\end{abstract}

Keywords: Solar eclipse, historical eclipses, social impact of eclipses, eclipse inscriptions, solar eclipses in Sri Lanka.

\section{INTRODUCTION}

Total eclipses of the sun have perplexed humanity since time immemorial. In earliest days it was exclusively a cause of fear. Naturally, when a sudden darkness befalls middle of the day, a frightened food gatherer or a hunter will be bewildered to see the obscured sun. Although total eclipses of the sun are very rare within a locality, humans recollect their memories and pass information from generation to generation and reoccurrences of solar eclipses established itself as a fact. Unlike phases of the moon, the pattern of periodicity of solar eclipses was not something easy to fathom. Fear and possibly the consideration of obvious consequences of something happening to the sun, made people to assume solar eclipses an evil. They seemed to appear once in a way just as social calamities. Many cultures attributed latter to deities. Likewise, the former was also believed to be a result of their involvement. In Hindu mythology, the legend that has transcended to Sri Lanka as well, eclipses are caused by the bodiless deity Rahu who devours the sun. Chinese thought that a sky dragon attempts to eat the sun (Shylaja \& Madhusudan, 1999). Widely different ancient cultures, attribute solar eclipses to engulfing of the sun by evil celestial beings. Man in seeking explanations to happenings in the environment, connects them to familiar concepts.

Around $500 \mathrm{BCE}$ the cause of the solar eclipses was explained as shadowing of the sun by moon's disc at new moon. However, superstitions persisted, along with questioning and understanding. Advancement of astronomy enabled prediction of eclipses with utmost precision and despite intelligentsia openly declaring these heavenly events bear no adverse effects (i.e. Walters, 1999), misbeliefs continued perhaps to a lesser degree.

With the development of modern physics, occasions of total eclipses of the sun provided opportunities for important measurements. Scientific agencies in affluent nations arranged expeditions to lands afar for observing solar eclipses (Soojung-Kim Pang, 2002). These activities promoted public and political interest in solar eclipses, arousing the curiosity of laymen.

"Corresponding author (ktenna@yahoo.co.uk; (iD https://orcid.org/0000-0003-2613-9214) 
Today, the eclipse superstition has faded much and public look upon these events as rare awesome displays in the sky which people should enjoy. Media presentations, masses flocking to see a total solar eclipse entail healthy social interaction, providing much needed non-material benefits to the society. Study of past solar eclipses in relation to history provide valuable chronological information and indicate that these events have had an impact on society.

\section{ECLIPSE SUPERSTITIONS: THEIR HISTORICAL AND SOCIAL SIGNIFICANCE}

Eclipses have also been viewed as expression of anger or warning by the gods for human sins and a sign of misfortune. History records many instances where appearance of solar eclipses ending wars and fighting parties agreeing for truce (Chambers, 1908; Steel, 1999; Berkowitz, 2017). According to Greek historian Herodotus, the eclipse of May 28, 585 BCE ended the war between Medes and Lydians in a part of present day Turkey. Having sighted the eclipse and considering it a celestial warning, parties agreed for settlement (Steel, 1999).

The rich literature in ancient Indian chronicles, Rigveda, Ramayana and Mahabharata refer to solar and lunar eclipses, frequently pointing them to conflicts (Dwivedi, 2006; Shylaja \& Madhusudan, 1999). In Rigveda, the demon responsible for causing eclipses was named Svarbhanu, whereas in puranic Hinduism, one who engulfs the sun is Rahu. Rigveda says eclipses will have malefic effects on earth and worlds of gods (Dwivedi, 2006). In South East Asian countries there had also been customs and traditions to be followed during and after a solar eclipse (Chambers, 1908). Chinese Emperors engaged astronomers equipped with observatories to keep an eye on the sky and immediately report eclipses, so that drummers could make loud noise to chase the demon supposed to be devouring the sun (Shylaja \& Madhusudan, 1999; Berkowitz, 2017).

Until recent times, kings and noblemen in India used to present donations to temples after a solar eclipse thinking such deeds would dispel any adverse aftermath influence and for repentance. Indian Vedic scripts also state that it is virtuous to grant donations to Brahmins and poor during solar eclipses (Dwivedi, 2006). Tibetan Buddhists believed that the after effects of one's good and bad deeds multiply thousand-fold during a solar eclipse (Bilung, 2015). Superstitious beliefs continued even after eclipses were understood to be a natural phenomenon. A large number of copper plates and stone inscriptions discovered in India announce donations (normally land or gold and tax exemptions) granted to temples by the rulers, after sighting a solar eclipse in their skies (Vahial \& Subbarayappa, 2011). Information therein has been used to determine the chronology of historical events more reliably. Sri Lankan kings seemed to have followed the same tradition and one instance of concrete evidence exists (i.e. De Zoysa, 1873).

\section{Ramayana eclipse story}

Valmiki's epic Ramayana accurately describes the total solar eclipse phenomenon stating that the event occurred at the time of the war of Khar and Dushan with Rama. According to the story, Rama, Sita and Rama's brother Lakshmana were hiding in the scenic demon infested forest of Panchavati. One day the demon Surpnakha, the sister of King Ravana of Lanka, disguised as a princess, approached Rama and pleaded him to abandon Sita and accept her as his wife. When Rama refused, the angered demon returned to her true personality, erupting a brawl with Lakshmana and Rama. Lakshmana's arrow wounded Surpnakha's face and in vengence, she returned, accompanying her brothers Khar and Dushan and an army of demons to start a battle. Valmiki says, when Khar turned his army to attack Rama, a portion of the sun gradually turned black developing a brightly colored periphery, as if charcoal were moving across the sun. Daylight diminished in all directions, progressing to a late afternoon of redness resembling that of a fresh wound. As darkness approached and sun lost its lustre, although it was not new moon or full moon, sun was engulfed by Rahu. It was like nightfall, stars appeared in the sky and animals howled in the dusk. The above description of the eclipse given in the verses 3.23.1 to 3.23.13 of the Aranya Kand of Ramayana (translation in IIT Kanpur website, 2017) quite accurately describes the phenomenon. Either Valmiki has seen a total solar eclipse himself or learnt the details from authentic sources quite recent to his time and not from much older scripts or hearsay. There are claims that the eclipse referred to by Valmiki could be the one that occurred on $7^{\text {th }}$ October 5077 BCE visible to southeastern region in India named Panchavati (Bhatnagar, 2004). However, many authorities are of the opinion that Ramayana was written much later, presumably around 500 BCE (Keith, 1915; Guruge, 1991). The author of the present work suggests the following alternative. Valmiki is supposed have lived in Avani, a location close to Mulbagal in the Mysore district of India (Rice, 1876; Lal, 2009). Perusal of NASA Eclipse Website (NASA Eclipse Web Site, 2016) reveals, a total eclipse of the sun, lasting for more than 3 minutes had crossed Avani (Lat.13.1072, Long.78.3173) on $22^{\text {nd }}$ July 495 BCE. Totality included a $220 \mathrm{~km}$ wide strip of land between the parallels joining Kanpur to Tirupathi and Thrissur to Puducherry. First-hand experience with the spectacular event may have fascinated this genius 
so much to paint poetically the war of Rama with Khar. The writer of the epic, stating that the sun was engulfed by Rahu, although it was not new moon or full indicate that he is well aware that real eclipses of sun and moon happens on new moon and full moon.

\section{Nagadeepa Eclipse}

Sri Lankan historical cronociles, Dipavamsa and Mahavamsa state that, as Buddha arrived in Nagadeepa, northern seaport in Sri Lanka, to settle a dispute between Naga king Mahodara and his nephew Culodara, the sky darkened scaring the two fighting groups, who stopped the war and, thereafter, the sun brightened. There had been a total eclipse of the sun on April $19^{\text {th }} 481 \mathrm{BCE}$ visible to Nagadeepa. As there were no other solar eclipses within the historical period, it has been suggested that the Naga War in Sri Lanka ended in 481 BCE (Munasinghe \& Ratanatunga, 2012).

The Mahavamsa describes another similar episode. According to this chronicle, when Yaksas were meeting in Mahiyangana, Buddha visited the site, darkening the sky to scare Yaksas. No total eclipses of the sun can be identified to tally with two incidents (Nagadeepa and Mahiyangana). As pointed out by Gooneratne (2009), Buddha never thought of doing things to scare anyone. His truly intellectual and rational stance has been to explain and convince by giving examples. Possibly these references to darkening of the sky are phrases borrowed from Indian texts (Gooneratne, 2009). Their correlation to a real physical incident that happened is a possibility.

\section{Solar Eclipse of $4^{\text {th }}$ May 249 BCE and King Asoka's Pilgrimage to Lumbini}

According to an inscription in Lumbini, Nepal, Emperor Asoka had pilgrimaged to Lumbini - the birth place of Gautama Buddha - 20 years after coronation (UNESCO, 2013). The inscription in a red sand stone pillar written in Brahmi, when translated into English (Buher, 1897) reads,

"King Piyadasi (Asoka), beloved of devas, in the $20^{\text {th }}$ year of coronation, himself made a royal visit. Buddha Shakyamuni having born here, a stone railing was built and a stone pillar erected. Bhagavan having been born here, the tax from village of Lumbini was reduced and entitled to eight part only".

The above inscription, uncovered by a German archeologist is placed in the Mayavati Temple in Lumbini. Most Asoka pillar inscriptions do not declare donations or concessions, but here the edict implies that the tax owed by the village of Lumbini has been reduced to one eighth of its income.
Emperor Asoka's magnanimous contribution towards dissemination of Buddhism and building Buddhist stupas all over his empire is well known. The Sanskrit text Divyavadana, says that the Emperor wished, all Buddha's relics be deposited in all the stupas simultaneously and the signal given has been a dimming and brightening of the sun- implying a solar eclipse (Eraly, 2002). As the year of Asoka's coronation is believed to be either in 268 or $269 \mathrm{BCE}$, the period he went on pilgrimage to Lumbini should be 248 or 249 BCE (Smith,1901). Although there are uncertainties in the chronology, Emperor's invigorated pronouncement of Buddhism and the order to build stupas appears to be around the same period. The Divyavadana reference, has led to the speculation that Emperor Asoka visited Lumbini as a pledge made after appearance of a solar eclipse (Eggermont, 1956; Eraly, 2002). Rulers visiting temples after solar eclipses and granting donations was a tradition in ancient India. There is evidence to the effect this practice continued from $3^{\text {rd }}$ centuary BCE until very recent times (Upadhayay, 1994; Vahial \& Subbarayappa, 2011; Shylaja \& Kaidala, 2012).

Conspicuous solar eclipses which had occurred in the region covered by the Asoka Empire in the $2^{\text {nd }}$ and $3^{\text {rd }}$ centuries BCE (NASA Eclipse Website, 2016) are given in Table 1.

Table.1: Total and annular solar eclipses occurred in the region of Asoka Empire during the 300-100 BCE

\begin{tabular}{lr}
\hline Date (BCE) & $\begin{array}{r}\text { Eclipse Type (within Asoka } \\
\text { Empire) }\end{array}$ \\
\hline 115 Aug 04 & Total \\
181 March 04 & Total \\
195 June 06 & Total \\
232 Nov 10 & Annular \\
228 Sept.07 & Total \\
249 May 04 & Annular \\
275 Mar 24 & Total \\
282 Aug 06 & Total \\
\hline
\end{tabular}

There had been a total eclipse of the sun on $4^{\text {th }}$ May 249 BCE. Although the obscuration at Pataliputra (present day Patna 25.6 N, 85.1E) was $~ 73 \%$, path of totality crossed Afghanistan, Pakistan, Jammu, Kashmir and several other regions of Northern India; all within Asoka's Empire. News of total darkness in distant parts of his Empire, could have reached him, latest in about 2-3 months. Thus the Emperor was in a position to visit Lumbini in the same year (249 BCE). As the thinking prevalent at the time that eclipses are godly warnings and his remorse and recollection of past, may have prompted him to visit Lumbini as early as possible. 


\section{Eclipses in Samyutta Nikaya}

References to eclipses, earlier to Asoka period could reveal interesting information related to ancient Buddhist chronology. The Buddhist Scripture Samyutta Nikaya, narrate two discourses (Suttas in Pali), named Candima Sutta and Suraya Sutta (Tipitaka English tranalations, 1999a;1999b). Former says, once upon a time when Buddha was residing in Jetawana, Sharavasthi, the Moon Deity, pleaded Buddha to release him from the grip of Rahu as the demon listened to the word of Buddha. In the exactly parallel Suraya Sutta, the Sun Deity, pleads Buddha to relieve him from the grip of Rahu. Possibly, Lunar and Solar eclipses were pictured in this manner to imply the superiority of Buddha over Hindu Gods as the cause of eclipses agree with the ancient Hindu version. In 1947, Sengupta, a Professor of Mathematics, Calcutta University, attempted to calculate the dates of these eclipses (Sengupta,1947). However, the computation techniques and compilation eclipse dates available at the time were not exhaustive and not sufficiently reliable. The author of the present work analysed the data on solar and lunar eclipses published in the NASA Eclipse Web Site (2016), to determine whether historical eclipse occurrences can be associated with incidents described in the Samyutta Nikaya.

Generally, lunar and solar eclipses occur in pairs of one lunar and one solar happening within period of about one month, i.e., a lunar eclipse precedes or follow a solar eclipse seen somewhere in the world and vice versa. It would not be too much of a speculation to assume that Samyutta Nikaya, refers to two such consecutive events. Furthermore, both eclipses must be visible to Jetawana (Lat. $27.51^{\circ} \mathrm{N}$, Long. $82.04^{\circ} \mathrm{E}$ ) near Sharavathi. Penumbral lunar eclipses can also be excluded, because they do not appear as eating piece of moon but only change in the tint of the full moon, hardly detectable by unaided eye. Solar and lunar eclipse pairs, satisfying above criteria, occurred from (700 - 400 BCE) are given in the Table 2. Sengupta has identified only the events corresponding to entry in the $3^{\text {rd }}$ row of Table 2 . (Sengupta,1956).

It would be premature to make definite conclusions from the above findings. The details related to the time period of writing of these scripts, sources used for collecting information, any subsequent revisions etc. need to be considered and the subject warrants further study. The solar eclipse of $14^{\text {th }}$ January 559 $\mathrm{BCE}$, recorded in the list of solar eclipses compiled by Confucius is said to have occurred two years before his birth. Although Sengupta has suggested that, the lunarsolar eclipse pair in the third entry of the Table 2 could be one that corresponds to Samyutta Nikaya, the present author believes that more extensive study of Buddhist chronology and Indian history needs to be conducted to rule out other options given in the Table 2 and form a more convincing argument.

\section{The annular eclipse of $13^{\text {th }}$ January 1507 sighted by Portuguese in Colombo}

An annular solar eclipse crossed Sri Lanka on $13^{\text {th }}$ January 1507 visible to the whole Island, except a partial eclipse in far north. According to NASA World Atlas of Eclipse Paths (NASA Eclipse Web Site, 2016), to observers based in Colombo, the eclipse began at 11.24 a.m., reaching the annularity which lasted for $5 \mathrm{~m} 8 \mathrm{~s}$, starting at 12.17 p.m. and the partial phase ending at 2.50 p.m. Many living in Sri Lanka at the time would have been fortunate to witness this spectacular event because of clear skies in the month of January.

An extract from a translation of a letter said to have been written by Dom Francisco de Alameda, the viceroy of Portuguese India to King Manuel I in

Table 2: Solar and lunar eclipse pairs visible to Sharavati, India 700-400 BCE

\begin{tabular}{lr}
\hline Date of Solar Eclipse (BCE) & Date Lunar Eclipse (BCE) \\
\hline $13^{\text {th }}$ December 614 & $27^{\text {th }}$ November 614 \\
$7^{\text {th }}$ March 572 & $22^{\text {nd }}$ March 572 \\
$14^{\text {th }}$ January 559 & $29^{\text {th }}$ December 560 \\
$16^{\text {th }}$ February 505 & $31^{\text {st }}$ January 505 \\
$22^{\text {nd }}$ September 498 & $8^{\text {th }}$ September 498 \\
$23^{\text {rd }}$ September 471 & $8^{\text {th }}$ October 471 \\
$20^{\text {th }}$ March 451 & $5^{\text {th }}$ March 451 \\
$26^{\text {th }}$ December 447 & $11^{\text {th }}$ December 447 \\
\hline
\end{tabular}


Lisbon, describing his son Dom Lourenco de Alameda's encounter with Ceylon is copied below. This letter is printed as a foot note in the article tittled "Discovery of Ceylon" by Ferguson (1907).

"We are much troubled by reason that no ship of the fleet has come this year, and Moors are strengthening themselves along the coast against us. Barros tells the same thing at greater length and states that the minds of the Portuguese were still further troubled by occurrence, on Wednesday $13^{\text {th }}$ January 1506 , of an eclipse of the sun, which lasted from hours 11 to 2.30 p.m., and $15^{\text {th }}$ July 1507 of a severe earthquake, lasting an hour with some intervals."

NASA 's calculation of dates and times of solar eclipses are very precise and any error in time for an eclipse that occurred 500 years before cannot be more than few minutes. Therefore, the eclipse referred in the above letter is certainly the eclipse of Wednesday $13^{\text {th }}$ January 1507 and dating the year as 1506, is an error. Times of visual observation mentioned by Portuguese in Colombo during that day are consistent with NASA prediction (NASA Eclipse Web Site, 2016). Therefore, the above letter make sense if and only if 1506 is replaced by 1507 . There could be inadvertent errors in dates found in letters and scripts, but eclipse calculations today are reliable to an accuracy less than few minutes per century. Thus it is certain that Portuguese were in Colombo, in January 1507, suggesting Portuguese arrived Sri Lanka in 1506 rather than 1505.

An earthquake dated as July $15^{\text {th }} 1507$ referred to in the letter seems to be authentic and confirms year in question is 1507 and not 1506. Author found independent evidence to the effect that there had been an earthquake in the region on this date. An inscription in Nelamangala, South India says that a tremor shook earth four times on a Thursday around July-August in the year 1507 (Igenar et al , 1999; Rice, 1897 ) and July $15^{\text {th }}$ is indeed a Thursday. Most probably this was a quake epicentered in Indian Ocean, felt more strongly in Colombo but not devastative. The exact date of arrival of Portuguese is controversial (Rohanadeera, 1996 ; Kumara, 2016; De Silva, 2016 ). The eclipse and the earthquake, determine with certainty that Portuguese were in Sri Lanka from $13^{\text {th }}$ January 1507 to $15^{\text {th }}$ July 1507 . The above fact may help historians to fix the date of arrival of Portuguese in Sri Lanka.

It is most unlikely if the administration in Kotte did not take any notice of the annular eclipse of $13^{\text {th }}$ January 1507, because much less conspicuous partial about a decade later has been an officially significant event to the King of Kotte, as discussed in the next section.

\section{Udugampola Solar Eclipse $1^{\text {th }}$ June 1517}

Around 1870, a women digging the ground searching edible yams in a cinnamon plantation near Kadirana (a village close to the city of Negmbo in Gampaha District, Sri Lanka ) found a copper plate with engraved letters. The item handed over to the authorities, deciphered and tranalated into English by Mudliar L. de Zoysa - the Chief Translator to the Government of Ceylon in 1873 - was found to be an informative inscription (de Zoysa, 1873). The translation reads:

"On the fifteenth day of the dark half of moon, in the nineth year of the reign of Sri Vijayabahu, linellay decended from happy illustrious progency of Valvasuta Manu born of the solar race of Raja Sumitra of pure race, the lord of three Sinhala and the lord of nine gems- His Majesty by royal command delivered while seated at the new palace at Udugampola in midst of all engaged in affairs, has granted for a second time, on the day of an eclipse of the sun, by the way of a second grant, on terms of the previous grant received from the Court of Kurunegala the field Wala Palle Reruwila situated close to the field Lindora Akata Diwela, Kekulan Owita together with villages, trees and jungles, fields, Owitas belonging to Nilaya of two pelas of husked rice of Dombawela belonging to Udugampola Aluthkuru Korale to Brahmin Venrasu Konda Perumal, making protection so that the grant may endue permanently. In proof whereof, copper sannasa written and granted to Konda Perumal".

Inscription states that, on command of the Emperor Srisangabo Vijayabahu (Vijayabahu VI) seated in the midst of dignitaries in a Royal Assembly held at his new palace in Udugampola, on new moon day of June, in the eighth year after his accession to the throne - the day a solar eclipse occurred, a donation of land has been granted to a Brahmin named Konda Perumal recording in an inscription written on a copper plate. The wording in the original and the Sinhala translation of the inscription (de Zoysa, 1873) also suggest a ritual has also been conducted in the Udugampola palace to drive away permanently any ill effects of the eclipse.

Vijayabahu VI is supposed to have ascended to throne after death of his father Veera Parakramabahu VIII. Here the Sri Lanka's history is somewhat masked by the controversy of Dharma Parakramabahu, supposed to be an interim ruler just before the death of Veera Parakramabahu VIII (Rohanadeera, 1996).

The NASA World Atlas of Eclipse Paths (NASA Eclipse Web Site, 2016) prove that there was an annular 
solar eclipse over South India on $19^{\text {th }}$ June 1517 visible to Sri Lanka as a partial eclipse. At Udugampola (Lat.7.125N, Long.79.978E) in Gampaha District, the eclipse started at $2.53 \mathrm{pm}$ reaching a maximum obscuration of $68.52 \%$ at 4.30 p.m. and ending at 6.33 p.m. At the above maximum level of solar obscuration, in the early afternoon hours, the effect of eclipse should have been readily noticeable as reddened evening like appearance. Paranavitana (Paranavithana, 1961) has calculated the new moon day as $18^{\text {th }}$, actually new moon of June 1517 was on $19^{\text {th }}$ and not in $18^{\text {th }}$. The eclipse that occurred in June 1518 was not visible to Sri Lanka as correctly pointed out by him earlier. Thus the conclusion arrived at, that is Vijayabahu VI ascended to the throne in 1509 (i.e, Paranavitana, 1961) is confirmed.

The inscription as in the original version (de Zoysa, 1873) suggests that the copper plate has been engraved and handed over to Brahmin Konda Perumal on the day of eclipse itself. Copper plate scripting, common in India has also been practiced in Sri Lanka (Dias, 2003). Compared to writing on copper foils, engraving on plates require special skills, probably perfected by that time. Inquires made by the author, revealed that the village Wadumulla, few miles from Udugampola continued to be a center of blacksmiths and goldsmiths until recent times. Probably, the King summoned smiths to the palace.

An obscure component of the inscription is the reference to a previous grant in the Kurunegala period and therefore, around two hundred years earlier. No known evidence exists to determine the merit and the details of the recipient. An ancient Hindu temple in Kadirana, continues to date. Perhaps, the Court of Kurunegala had honored a donation to this temple. What is the relevance of the first grant (Kurunegala) to the second (Udugampola)? Could it be another solar eclipse? A total solar eclipse visible to Sri Lanka of duration nearly three and half minutes (at Colombo, Negmbo, Kurunegala) occurred on $5^{\text {th }}$ July 1293 (NASA Eclipse Website, 2016). However, these speculations needs confirmatory evidence.

Date of the eclipse confirm that Vijayabahu VI ascended the throne in the year 1509. It is said that when his father Veera Parakkramabahu in Kotte died, people wanted his son, Sakalakala Vallaba- the Provincial King of Udugampola to accept the throne, but he declined and crowned his brother as Vijayabahu VI (Seneviratne, 1913).

The Portuguese author Fernao De Queyroz, also refers to a solar eclipse like incident in Sri Lanka. In his book on conquest of Ceylon by Portuguese, De Quevroz (1930) says, when Lopo Sorez arrived in
Colombo accompanying a fleet of ships to build a fortress, the area was surrounded by Sri Lankan soldiers and a battle erupted. However, the conflict did not go far as sky darkened as if the evening has approached early. De Queyroz's description fits precisely into the conditions at time of eclipse of June 1517 . Generally cloudy weather of June in Colombo, 68\% obscuration of sun around 4.30 p.m. would certainly appear as a very early setting of the evening. According to Rohanadeera (1996), this should be the very same eclipse recorded in the Kadirana inscription. The year of invasion by Lopo Sorez has been documented as 1517 (Ferguson, 1907; Rohanadeera, 1996). Though not ruled out, it is too much of a coincidence to assume that Lopo Sorez came to Colombo on the day of the eclipse. Probably, there were sporadic encounters of Portuguese navy and natives for an extended period. King Vijayabahu's center of administration was Kotte. Inscription also refers to his new palace in Udugampola. Probably he had shifted to Udugampola, envisaging the possibility of a Portuguese invasion of Kotte.

After arrival of Portuguese in Sri Lanka, two other conspicuous solar eclipses have appeared, an annular eclipse on $13^{\text {th }}$ January 1507 - noted by Portuguese discussed previously- and a partial eclipse of over $90 \%$ obscuration on $14^{\text {th }}$ January 1553 , both visible to most regions of Sri Lanka. Though evidence has not been found yet, it is very likely that Sri Lankan rulers at the time have noted them. In India, a large number of copper plate and stone inscriptions attributed to donations by rulers to Hindu temples during solar eclipses have been documented (Upadhayay, 1994; Vahial \& Subbarayappa, 2011; Shylaja \& Kaidala, 2012). The Kadirana inscription shows that Sri Lankan kings had followed the same tradition.

\section{Total eclipses of the sun visible to Sri Lanka, that occurred after $300 \mathrm{BCE}$}

The Table 3 gives the total eclipses of the sun which had occurred after $300 \mathrm{BCE}$, visible to Sri Lanka. The last two entries in the Table, the events of $12^{\text {th }}$ December 1871 and $20^{\text {th }}$ July 1955 are well known. Author could not find any recorded event in the history of Sri Lanka that could be associated with any of the other eclipses. Going through vast literature, looking for incidental references to events of this nature is not easy. However, undertaking such studies further, worth the effort as a means of setting the historical chronology accurately. Particularly important exercise would be an analysis of historical literature to see whether any events could be related to the eclipses of 335 BCE July 04 and 1293 July 05 . The former could correspond a very peaceful early Anuradhapura era and latter possibly literally rich 
Kurunegala Period. During the above period, quite a number of annular and partial eclipses of the obscuration exceeding $90 \%$ have passed through Sri Lanka. Here again the author could not unearth any records, except those that occurred during the Portuguese period, discussed in the previous sections. Solar eclipses, visible to Sri Lanka during the time of British occupation were recorded in Ceylon Almanc and in some instances, newspapers.

\section{ECLIPSE PREDICTION}

The concept of predicting a solar and lunar eclipse has been there in the human mind from the earliest times. The motivation being, the necessity for advanced preparation to drive away evil spirits interfering the sun, demonstration of one's astrological foretelling powers as well as intellectual reasons. A legend tells that the Chinese Emperor Chung Kang ordered execution of his royal astronomer for not being able to predict the solar eclipse that occurred on 2159 BCE (Brown, 1931; Berkowitz, 2017). Eclipses were considered celestial signals, especially bad for the rulers, therefore, knowing its occurrence in advance was important to arrange rituals. Some Greek rulers have made a commoner to disguise as the king during a solar eclipse and after the eclipse, the poor man was executed (Berkowitz, 2017).

Astrologers promoting themselves, announcing their foretelling capabilities must have been quite common in ancient India. According to Sigālaka Sutta in the Buddhist scripture, Digha Nikaya (Walshe, 1995), one should not make a living by predicting solar and lunar eclipses or any foretelling based on stars. This is not banning astronomy. It is a recognition of superstitious business as a practice that do more harm than good to society and exemplify rationality of Buddhism. Although superstitious beliefs were highest in ancient Hindu culture, the basis for scientific astronomy originated in India and later transferred to China and Islamic World and from there to the West (Thompson, 2004). Easterners as well as Westerners have attempted to predict eclipse occurrences, before gaining a physical understanding of the phenomenon (Shah, 2015). Such attempts have not failed completely. Ancient Hindu astronomers and astrologers, after centuries of experience, have developed empherical techniques for computing solar and lunar eclipse dates (Spottiswoode, 1863). Although errors occurred in some instances, successful predictions have also been made. In this context an interesting incident that happened in Batticaloa during the time of a partial eclipse of the sun has been cited by Emerson Tennent (Tennent,1850).

On March $21^{\text {st }} 1825$, a partial solar eclipse occurred and was seen in Batticaloa. This event has been predicted earlier by a Hindu Brahmin Visvanathan Sathree, living in the same area, said to be the $11^{\text {th }}$ in a geneology of hindu astronomers. He had compiled his own ephemeris, giving the date, time and the percentage of obscuration. Christian Missionaries from America in Batticaloa, also knew the time of the eclipse (probably from the Nautical Almanic they possed). The time predicted by Visvanathan disagreed slightly with Missionaries version. Acoording to Visvanathan, the eclipse should begin 15 min later than time given by the Missionaries.

\begin{tabular}{lr} 
Table 3: Total eclipses of the sun that occurred after 300 BCE and visible to Sri Lanka \\
\hline Date & Region of Visibility \\
\hline 375 BCE Feb. 28 & Jaffna \\
353 BCE June 24 & South-East \\
335 BCE July 04 & Almost whole Island \\
133 BCE June 01 & Almost whole Island except far North \\
327 BCE June 06 & South East \\
653 BCE June 01 & South \\
834 BCE Sept. 07 & South \\
866 BCE June 16 & Jaffna \\
953 BCE Apr.6 & Northern Tip \\
977 BCE Dec 13 & Southern Tip \\
1293 BCE July 05 & Almost whole Island \\
1871 BCE Dec. 12 & Northern Sri Lanka \\
1955 BCE $20^{\text {th }}$ July & Almost whole Island \\
\hline
\end{tabular}


Another influential Brahmin from Batticaloa arranged a contest, to determine who is right and a large crowd gathered near the Missionary School, just before the eclipse. Visvanathan was in error and eclipse occurred exactly as stated by the Missionaries. Still, at the time fortelling an eclipse to accuracy of fifteen minutes is a commendable feat.

A paradigm shift in human thinking has seen the recognition that eclipses happen as a natural consequence, rather than a work of deities. Around 500 BCE, Anaxagoras and several other thinkers seem to have concluded that the shadowing of the sun by moon is the cause of a solar eclipse. The fact that solar eclipses happen at new moon and the crescent appearance of the sun during a partial eclipse, may have been the clues leading to the development of this conclusion. The Greek philosopher Thales of Miletus is said to have foretold the solar eclipse of 585 BCE Babylonians, more than 4000 years ago noted cycles in solar eclipse occurrences and successfully predicted some eclipses (Neugebauser, 1975). The Indian astronomer, Ariyabatta (490 CE) was probably the first to develop a mathematical scheme for predicting eclipses, calculating how the moon's shadow moves over the surface of earth (Kern, 1990). Much more precise science of eclipse prediction, originated after Copernicus revolution and formulation of theory of mechanics by Isaac Newton. Edmund Halley, famous for the comet, used Newton's Theory to predict the eclipse of May 1715 to minute's accuracy and openly declared that eclipses are a natural phenomenon and they pose no ill effect to the King or anyone else (Pasachoff, 1999). The German Astronomer, Friedrich Bessel (1820) perfected the method of calculating solar eclipse paths- the method used to date (Neugbauser,1975).

Despite all these achievements eclipse superstitions did not go away immediately. As Shakespeare said in the tragedy King Lear,

"These late eclipses in the sun and moon portend no good to us: though the wisdom of nature can reason it thus and thus, yet nature find itself scourged by sequent events" (Shakespeare,1605).

Efforts to dispel eclipse myths also gained momentum. During the time of American Revolutionary War in 1778, an eclipse of the sun was to happen on the $24^{\text {th }}$ of June. On the day of the eclipse, General George Washington was holding a war council. Previous to the meeting, Washington had sent a message to his commanders in the Continental Army, alerting coming phenomenon and preempting the apprehensions of the soldiers (Bernstein, 2017).

\section{ECLIPSE EXPEDITIONS}

When solar eclipse prediction calculations reached a good degree of accuracy allowing precise determination of the location and the time of totality, scientifically literate affluent nations organised eclipse expeditions (SoojungKim Pang, 2002). Eclipses offered opportunities for studying the outer atmosphere of the sun (corona) and conduct delicate experiments that could not be conducted in a laboratory. Apart from science, these expeditions contained a political and social perspective. Inter-governmental relationships and arrangements for transporting and housing equipment required interaction with local community. Media attention to these activities promoted eclipse awareness. Scientific glorification of eclipses amazed the community, persuading a few to reconsider superstitions. The eclipses most significant in the above context were those that occurred on $27^{\text {th }}$ August 1868, where the King of Thailand played a key role and the eclipses of $29^{\text {th }}$ May 1919 and $21^{\text {st }}$ September 1992, when experiments were planned to test the Einstein's General Theory of Relativity.

Perhaps no other ruler had exercised so much authority to the cause of a total eclipse of the sun than King Mongkut of Siam. Mongkut, a son of King Rama II of Siam was ordained as a Buddhist priest at the age twenty and during twenty-seven years of priesthood, he studied Pali, Astrology, Sinhala Chronicles, Mathematics and Astronomy. He was fascinated by western science, rejected the concept of Traiphum (worlds with senses, with form and without form) in traditional Thai Buddhist Philosophy and saw rationality in Buddhism. As an heir to the throne, he was crowned in 1851 and even he continued studying astronomy thereafter. His interest in western science, paved way for initiating healthy, scientific and political contacts in the west, enabling modernisation of education in Thailand (Griswold, 1961; Johnson, 1977).

When European astronomers were contemplating the working out of the path of the total solar eclipse of $18^{\text {th }}$ August 1868, King Mongkut calculated path himself, suggesting Hua Wan a coastal area in his country, as the best location. French astronomers confirmed his calculation requesting permission for an expedition, which was granted. The King, well in advance, built a palace for himself and a city for visitors in Hua Wan. Ships carried equipment, invited visitors and catering was assigned to local as well as French and Italian chefs. More than hundred elephants stood in the site for a ceremony in the day of the eclipse. He requested his countryman to be clam and quite during time of the eclipse, saying that it bears no ill effects and not to be 
fooled by the astrologers. When the totality phase arrived, exactly as predicted, visitors and foreign scientists heard a loud noise of fire crackers and beating of drums. The villagers in the vicinity were carrying out traditional rituals to drive away the demon. The King, jokingly remarked, "they are celebrating my prediction". Two weeks after the eclipse, King Mongkut died of malaria. He had been bitten by mosquitos during the expedition.

\section{Enstein's Theory of Relativity and solar eclipses}

Albert Einstein's Theory of Relativity further glorified eclipses in the public eye. After formulating his theory of General Relativity, Einstein proposed that his theory can be tested by measuring the bending of light by the gravitational attraction of the sun, seen as a change in the apparent position of a star near the solar disc, during the time of a total solar eclipse. Greenwich observatory sent two expeditions, one to the island of Principe in South Africa and the other to Brazil to observe the eclipse of $29^{\text {th }}$ May 1919. Analysing results of the Principe observation, the British Astronomer, Arthur Eddington declared that the measurement agreed with Einstein's prediction, rather than result expected on basis of the theory of Newton (Eddington, 1919). Next day, the headlines in newspapers was on confirmation of Einstein in an eclipse experiment. Einstein was elevated to a scientific celebrity and solar eclipses aroused public curiosity. However, for good reasons, hard core scientific community did not accept the result immediately, demanding further inquiry. Thereafter, extensive plans were made to repeat the experiment at the forthcoming eclipse of $21^{\text {st }}$ September 1922. Effort probably had political tone as well. The British wished to see who was right, whether their Newton or German Einstein, since for them, supporting the eclipse observation would also be a gesture of reconciliation with Germany after World War I. Again, of this was also a time when anti-Jewish activities started brewing in Germany. Some in Germany may have considered, encouraging this experiment as a silent opposition to such activities, while other wished to see Einstein wrong, after repetition of the experiment. Reputed astronomers in United Kingdom, Germany, Netherlands, United States, India and Australia planned expeditions with generous support from their Institutions and Governments. Some of the proposed expeditions did not materialise for various reasons and world eagerly awaited the results of the observations conducted by British-Dutch-German collaboration in Christmas Island and United States- Australia team at Wallal in Australia. Astronomers, being cautious, did not release the results of the experiment immediately as in the 1919 measurement.

Although, the much-awaited Nobel Prize was in the horizon, Einstein decided to visit Japan, as the situation in Germany at time was not so conducive to Jewish intellectuals. Einstein embarked the Japanese steamer Kitano Maru $2^{\text {nd }}$ October 1922 with his wife Elisa at Marseilles, France. The ship was scheduled to stops at Port Said, Colombo, Singapore, Shanghai, and Hong Kong before reaching Tokyo. When Einstein arrived in Colombo, 26 $6^{\text {th }}$ October 1922, a well-informed reporter from Times of Ceylon interviewed him (Tennakone, 2011). He questioned him of the eclipse experiments and situation in Germany. Einstein had said, cloudy weather in Christmas Island had interrupted the measurements, however, better sky conditions permitted the Licks Observatory team in Australia (Campbell, 1922) to do the experiment and a favorable result is expected. Einstein has also expressed his admiration of the British Empire and its reconciliation efforts with Germany. According to notes in his diary, Einstein had also encountered a Sinhalese teacher in Colombo, who praised British Administration. When he reached Shanghai, the captain of the ship met him and handed over the telegram from Stockholm announcing the award of the Nobel Prize. These events once again aroused a public interest in solar eclipses. Virginia Woolf, in her easy "The Eclipse" says, when she and her husband Leonard Woolf went to Northern Britain to watch the total eclipse of June $29^{\text {th }} 1922$, the train was packed. Nobody said Hello but uttered Eclipse. Emboldening of eclipses by science around nineteen twenties, could have been one of reasons for unprecedented rush to see the eclipse.

\section{Total eclipse of $12^{\text {th }}$ December 1871}

During the time of British occupation of Sri Lanka a total eclipse of the sun passed through the island on $12^{\text {th }}$ December 1871, covering the region, north of the straight-line connecting Manner and Trikonamadu. The expedition sent by British Government had landed in Galle few days before the eclipse and instruments transported from Galle to Jaffna, Trincomalee and South India via a ferry (Lockyer, 1872; Soojung-Kim Pang, 2002). The reputed astronomer Norman Lockyer has given a lecture on the eclipse in Jaffna and the importance attached to the eclipse was evident as His Majesty's Secretary of State in London has requested the Governor General of Ceylon to accompany the eclipse team in Jaffna. Astronomers who visited Sri Lanka and India had commented how layman reacted to the eclipse. European observers stationed in Jaffna-Fort had heard dwellers nearby shouting at moment of totality, they were under the impression, that the European masters have come to remedy the situation (Lockyer, 1872). The villagers near the South Indian observation point had begun setting fire to grass, moment the totality started, to drive away Rahu and the police intervened to calm the situation. The foreign observers have also commented 
that Brahmins invoked fear among peasantry and exploited them (Soojung-Kim Pang, 2002).

\section{Total eclipse of June $20^{\text {th }} 1955$ seen in Sri Lanka}

The eclipse of $20^{\text {th }}$ June 1955 was the one with the longest totality in the $20^{\text {th }}$ century. At the optimum point positioned in the Indian Ocean, the duration of the total phase exceeded $7 \mathrm{~min}$. The path of totality covered almost whole of the Island except Jaffna and Southern Hambantota. Many living today, frequently recollect the event and the general atmosphere in the country at the time. More than six decades later, all attributes of the society, including the general rationale of thinking, attitude towards superstitions and science have evolved. What the author feels from his experience is, in mid nineteen fifties, Sri Lankans had more time for free thinking. Today people are preoccupied with a rushing routine and have less time for intellectual dreaming, which receives no encouragement. Superstition was more at that time, but more frequently questioned. Today, although probably a lesser numbers believe in superstitions, also a less question such issues, instead taking them as a part of the tradition. The attitude toward science has also changed. In early nineteen fifties many wished taking-up science as an intellectual adventure in concurrence with other things. Today arts, humanities, literature and pure science fall into the category of un-important and generally pursued, if there are no alternatives.

News of a total eclipse was in air, about two years before June 1955. Radio Ceylon and local newspaper covered of the subject exhaustively to the level of the layman. Notable were the articles written by E. W. Adikarm, who grasped science at a later stage. The average man or women's reaction was curiosity in a background of superstition plus a reverence for the Western Science. Although few seriously believed the story of Rahu, many considered the eclipse a bad omen. Eclipse was a topic of inquiry and gossip in the village boutique, bus and the railway station. A frequent argument has been the validity of the prediction and how it has been predicted. Many times, the author heard the uttering "let us see whether it is going to happen or not, we cannot fathom descriptions in newspapers. Strangely, a good number of educated older generation Sri Lankans at the time believed that event will happen exactly as predicted. They were not astronomers or mathematicians, but those familiar with almanacs issued in years before the independence. Preindependence almanacs; the Government of Ceylon Almanac and British Nautical Almanac gave dates and times of occurrence of solar and lunar eclipses indicating where (Latitude, Longitude) when they could be seen. To a person familiar with these annual publications, a lunar or a partial solar eclipse happening as printed in the almanac, was not something difficult to believe. Lately, these information disappeared from Sri Lankan almanacs.

Media highlighted the visit of scientists from, United States, Europe, India and Japan to conduct observations, indicating an item in their scientific agenda would be testing the Relativity Theory of Einstein. People have heard about Einstein and the rumour that his theory can be understood only by a handful in the world, has been a prevalent misconception. Public is aroused more by ideas they cannot fathom than by things they easily follow. Sri Lanka government did not grant permission for astronomers from Soviet Union to visit Sri Lanka. This was also topic of debate.

The eclipse occurred exactly as predicted, to the amazement of those who did not believe it as well as those who believed it would happen the way they have learnt. Around $10.30 \mathrm{am}$, the world seemed to darken as night, stars appeared in the sky and crows flew to their nests. The grandeur of the event at the time of totality was exactly the description of Valmiki in Ramayana. Unfortunately, a large portion of Sri Lankan population could not see the corona sun, because of the clouds. The sky was clear in region close to Veyangoda, where the author lived and an amateur from the area recorded the best photograph of the totally eclipsed sun. Foreign astronomers stationed in Anuradhapura and Polonnauruwa could not perform satisfactory measurements. End of the eclipse was like a verdict from heaven, which pleased both parties, believers and non- believers and a significant rise in the faith and veneration towards science.

The well-known "Vadakaha" incident was not regarded as an omen of the eclipse, but a pitfall of myth. Days before the eclipse a tabloid carried a note, claiming that drinking an extract of the dried fruits of Acorus calamus, during the time of a total solar eclipse, has a rejuvenating effect. If not for material running out of stock, few days before the eclipse, even larger numbers would have complained to dispensaries and native physicians, the symptom of vomiting caused by ingestion of Acorus calamus. Author remembers the firm stand of native physicians regarding "Vadakaha". They knew it acts as an emetic and never included into prescriptions in large quantities. An aftermath of the eclipse, though not so obvious was a more healthier attitude and confidence towards science.

\section{The Great American Eclipse}

The total solar eclipse of $21^{\text {st }}$ August 2017, christened The Great American Eclipse, traced a 70 miles wide 2800 miles long path across the United States. Undoubtedly, it 
is the solar eclipse viewed by the largest number of men, women and children to date and the one that received so much publicity well in advance. Ready access to information, reliability of information provided and motivation induced by media had prompted, interested parties to make plans for travel and lodging, well in advance. The eclipse was not something of long term commercial interest, yet public and private organisation in the area of totality, made arrangements to accommodate visitors.

Starting from very early morning, people flocked into parks, farms and especially, secured open areas. Interaction with strangers eagerly awaiting to glimpse the event was equally appealing. Although, the eclipse was the main topic, visitors expressed their personal concerns, as if in front of the sun that would be obscured soon, true human inner feelings open-out. Moment the lunar disc touched sun, attention focused to the sky, people looked-up wearing protective glasses. Thereafter, onlookers, relaxed a bit talking to each other. In a while, the background reddened, as if a most unfamiliar evening is approaching fast. People turned emotional, uttering poetic expressions moved to locations best to view the totality. Sky, darkened, the totally obscured sun was surrounded by glow. Eclipse ended, enthusiastic crowds sporadically commenting, what they saw worth the trouble taken in travelling excessive distances. Some said, they are a saddened, because their kith and kin couldn't make it, while others blamed the colleagues, for going to work that day- saying, this experience worth's million times, the one day pay. Days after the eclipse, the web was full of words of fascination. A heart breaking report was, about a very old man lying on the lap of a women and gazing the eclipse. She has said,

"he is my father ninety-four-years old and badly disabled after a stroke, I do whatever possible to comfort him. He has not seen a total solar eclipse, I accompanied him here to show the eclipse".

\section{CONCLUSION}

Man's thinking and all the other aspects of civilisation wholly relate to the terrestrial environment and the sky. One could present so many arguments to support the hypothesis that humans would not have achieved the present level of advancement, if the earth had no moon. The above discussion illuminate the idea that, though not to the same extent, the eclipses of the sun and moon also delivered a significant social impact and influenced the mode of human thinking. Fear aroused by eclipses led to superstitions and curiosity. Both had profound societal implications. Superstition evolved customs, such as donations to poor-a significant welfare-and to the cause of religion by grants to temples. Thinking that solar eclipse points an omen or a warning, influenced decision making by rulers, such as a truce ending a war or a king resorting to more benevolent rule. Although more evidence is required, the reason behind Emperor Asoka's sudden turning towards "Dharma" may be the solar eclipse of 249 BCE.

Curiosity and insistence by politically powerful hastened eclipse prediction greatly contributing to the science of astronomy. Accurate eclipse predictions, made it possible for scientific bodies in affluent nations to arrange eclipse expeditions. These expeditions, created public awareness, establishing intergovernmental interactions and disseminated scientific ideas to underdeveloped nations. With the advent of science and masses undestanding eclipses as a natural consequence, the attitude towards them gradually changed. Today, the eclipses are viewed more as rare awesome spectacles, which people get together and watch. The unique collective experience, benefits the society in providing much needed appreciation of things beyond the routine material world.

References to solar and lunar eclipses and eclipse like events, are numerous in literature and have attracted the attention of historians as means of fixing chronology. The present work gives an alternative interpretation of the eclipse recorded in Ramayana and identifies dates that might correlate with the solar and lunar eclipses of Samyutta Nikaya; these suggestions needs to be explored further. Portuguese history in Sri Lanka, refers to a letter written by Dom Francisco de Alameda, to the King of Portugual. According to this letter, Portuguese stationed in Colombo has observed a solar eclipse on $13^{\text {th }}$ January 1506 and noted an earthquake on July $15^{\text {th }} 1507$. Perusal of NASA Eclipse Website reveal, there had been an annular eclipse on $13^{\text {th }}$ January 1507 visible to Sri Lanka and historical records give evidence for an earthquake on $15^{\text {th }}$ July 1507 . This finding favors, 1506 as the year of Portuguese landing in Sri Lanka, rather than 1505.

A large number of stone and copper plate inscriptions found in India proclaim donations to temples and brahamins during the time of solar eclipses. Only one such inscription found so far in Sri Lanka, the Kadirana Sannasa, the date previously calculated as $18^{\text {th }}$ June 1517 . The NASA Eclipse Website confirm the eclipse, but the correct date is $19^{\text {th }}$ June 1517 . A number of prominent sloar eclipses have appeared in Sri Lankan skies after 300 $\mathrm{BCE}$. Author could not find definite records earlier than $1500 \mathrm{CE}$ and further search could be fruitful in revealing important chronological information. The study of historical and social aspects of eclipses, particularly in South East Asian region, is a rewarding exercise and worth the effort. 


\section{ACKNOWLEDGEMENT}

Author wish to thank Prof. Ajith de Silva, Department of Physics, University of West Georgia for reading of the manuscript and valuable comments.

\section{REFERENCES}

Berkowitz, B. (2017) The strangest, scariest eclipse myths throughout history, Washington Post [Online] $16^{\text {th }}$ August 2017, pp: 1-3, Available from: https://www.washingtonpost. com/graphics/2017/lifestyle/eclipse-myths/?utm term $=.2454035$ f0752 [Accessed: $3^{\text {rd }}$ March 2017].

Bernstein, L. (2017) Solar Eclipses in History: The Revolutionary War [Online] Available from: http://wjla.com/ news/nation-world/guatemala-erupting-volcano-killed-hurt [Accessed: $3^{\text {rd }}$ March 2017].

Bhatnagar, P. (2004) Dating the Era of Lord Rama, Calcutta: Rupa Publications.

Bilung, S. (2015) Superstitions on Solar and Lunar Eclipses [Online] Available from: https://www.slideshare.net/ SamriddhiBilung/superstitions-on-solar-and-lunar-eclipse [Accessed: $3^{\text {rd }}$ March 2017] pp: 1-3.

Brown, F. C. (1931) The Eclipses in China, Popular Astronomy, 39, pp: 567-572.

Buher, G. (1897) The Discovery of Buddha's Birth Place, Journal of the Royal Asiatic Society of Great Britain and Ireland, 2, pp: 429-433.

DOI: https://doi.org/10.1017/S0035869X00146040

Campbell, W. W. (1922) The total eclipse of September 21, 1922, Astronomical Society of Pacific, 35, pp: 11-44.

DOI: https://doi.org/10.1086/123262

Chambers, G. F. (1908) The story of eclipses, New York: D.Appleton and Co.

De Queyroz, F. (1930) The Temporal and spiritual conquest of Ceylon (trans. Perera, S. G.), Colombo: A. C. Richards.

De Silva, C. R. (2016) Portugual and Sri Lanka: Recent Trends in Histography, In Flores, J. (ed) Re-exploring the Link in History: Constructed Histories between Portugual and Sri Lanka, Wisebaden, Germany: Harrassowit Verlag.

de Zoysa, L. (1873) Transcript and Translation of an Ancient Copper Plate Sannas, Journal of the Ceylon Branch of the Royal Asiatic Society, 1, pp: 73 -78.

Dias, M. (2003) A new facet of our history buried with the copper plate of Codaganga, Sunday Island, October 2003.

Dwivedi, B. (2006) Scientific Basis of Hindu Beliefs, Delhi, India: Diamond Pocket Books.
Eddington, A. S. (1919) The total eclipse of the sun 1919 May and the influence of Gravitation on light, The Observatory, 42, pp: 119-122.

Eggermont, P. N. (1956) Chronology of the reign of Asoka Moriya: Comparison of the date of Asoka inscriptions and the date of the tradition, Leiden: E.J.Brill, pp: 168-169.

Eraly, A. (2002) Gem in Lotus: Seeding of the Indian Civilization, London: Penguin Books.

Ferguson, D. (1907) The Discovery of Ceylon by the Portuguse, Journal of the Royal Asiatic Society-Ceylon Branch, 59, pp: 284-385.

Goonaratne, R. (2009) Did Buddha visit Sri Lanka, Sunday Times, [Online] 13 ${ }^{\text {th }}$ December 2009, p: 3, Available from: http://www.sundaytimes.1k/091213/Plus/plus_12.html [Accessed: 29 ${ }^{\text {th }}$ December 2017].

Griswold, A. B. (1961) King Mongkut of Siam, New York: The Asia Society.

Guruge, A. (1991) The Society of Ramayana, New Delhi: Abhinav Publications.

Igenar, R. N., Sharma, D. \& Siddqui, J. M. (1999) Earthquake history of India in medieval times, Indian Journal of History, 34, pp: 181-234.

IIT Kanpur, Sloka \& Translation- Aranyakanda [Online] Available from: https://www.valmiki.iitk.ac.in/sloka?field kanda_tid $=1 \&$ language $=d v \&$ field_sarga_value $=1$ [Accessed: $20^{\text {th }}$ September 2017] pp: 2-7.

Johnson, D. C. (1977) Rationality in Biography of a Buddhist King, Mongkut, King of Siam (1851-1868), In Schober, J. (Ed) Sacred biography in the Buddhist Traditions of South and South East Asia, Honolulu: University of Hawaii Press, pp: 232-248.

Keith, A. B. (1915) The Date of Ramayana, Journal of the Royal Asiatic Society, 47, pp: 318-325.

DOI: https://doi.org/10.1017/S0035869X00048231

Kern, H. (1990) The Ariyabatta (2 ${ }^{\text {nd }}$ Ed.), New Delhi: Eastern Book Linkers.

Kumara, U. S. (2016) When did Portuguse arrive?, Ceylon Today, $3^{\text {rd }}$ July 2016.

Lal, M. (2009) Iron Tools, Forest Clearance and Urbanization of Gangetic Plains, In Rangarajan, M. (ed) Environmental Issues in India : A Reader, Boston: Pearson Education, pp: 18-32.

Lockyer, J. N. (1872) Contributions to solar physics, London: Macmillian.

Munasinghe, B. \& Ratnatunga, K. (2012) Astroarchalogy from Mahavamsa, In Samarasinghe, G. L. W. (Ed) Proceedings of the SAARC International Conference Archaeology of Buddhism (August 22-24), Colombo: SAARC Cultural Center. 
NASA Eclipse Web Site (2016) [Online] Available from: https://eclipse.gsfc.nasa.gov/eclipse.html [Accessed: $18^{\text {th }}$ September 2017].

Neugebauser, O. (1975) A history of ancient mathematical astronomy, Heidelberg: Springer.

DOI: https://doi.org/10.1007/978-3-642-61910-6

Paranavithana, S. (1961) The Emperor of Ceylon at the time of arrival of Portuguese, University of Ceylon Review, 59, pp: 10-29.

Pasachoff, J. M. (1999) Halley as an eclipse pioneer: his maps and observations of the eclipses of 1715 and 1724, Journal of Astronomical History and Heritage, 2, pp: 39-54.

Rice, B. L. (1897) Mysore: A gazetteer compiled for government, Westminster: A. Constable [Online] Available from: https:// archive.org/details/mysoregazetteerc01rice [Accessed: $17^{\text {th }}$ November 2017].

Rice, B. L. (1876) Mysore and Coorg : A gazetteer compiled for the government of India, Bangalore, India: Mysore Government Press [Online]Available from: https://archive.org/ details/cu31924071131605 [Accessed: 21 ${ }^{\text {st }}$ September 2017] pp: 106-107.

Rohanadeera, M. (1996) Dharma Parakramabahu, Vidyodaya Journal of Social Science, 7, pp: 13-45.

Seneviratne, J. M. (1913) The Date of Buddha's Death and Ceylon Chronology, Colombo: J. R. A. S. Publishers.

Sengupta, P. C. (1956) Dates of Principal Events of Buddha, Indian Historical Quarterly, 32, pp: 124-128.

Sengupta, P. C. (1947) Ancient Indian Chronology, Calcutta: University of Calcutta, [Online] Available from: https:// archive.org/details/ancientindianchr014482mbp [Accessed: $17^{\text {th }}$ November 2017].

Shah, J. (2015) Medieval Eclipse Prediction: Parallel Bias in Indian and Chinese Astronomy, Gaoita Bharata, 37, pp: 163178.

Shakespeare, W. (1605) The Tragedy of King Lear, Act.1. Scene .2.

Shylaja, B. S. \& Kaidala, G. (2012) Stone Inscriptions as records of celestial events, Indian Journal of History of Science, 47, pp: 533-538.

Shylaja, B. S. \& Madhusudan, H. R. (1999) Eclipse: A Celestial Shadow Play, Hyderabad: University Press.

Smith, V. A. (1901) The identity of Piyadassi with Asoka Maury and some connected problems, Journal of the Royal
Asiatic Society of Great Britain and Ireland, 3, pp: 827-858.

DOI: https://doi.org/10.1017/S0035869X00029026

Soojung-Kim Pang, A. (2002) Empire and Sun: Victorian Solar Eclipse Experiments, California: Stanford University Press.

Spottiswoode, W. (1863) On Surya Siddhantha and Hindu Method of Calculating Eclipses, The Journal of the Royal Asiatic Society of Great Britian and Ireland, 20, pp: 370-347.

DOI: https://doi.org/10.1017/S0035869X00165335

Steel, D. (1999) Eclipse, Washington D.C.: Joseph Henry Press.

Tennakone, K. (2011) Albert Einstein's Obscure Visit to Sri Lanka in 1922, The Island, $21^{\text {st }}$ January 2011.

Tennent, J. E. (1850) Christianity in Ceylon; with an historical sketch of the Brahamanical and Buddhist Superstitions, London: John Murray, pp:139-141.

Thompson, R. L. (2004) Vedic Cosmography and Astronomy, Delhi: Motilal Banarsidass.

Tipitaka- Samyutta Nikaya (1999a) Candima Sutta: Moon Deity's Prayer for Protection (SN 2.9) (trans. from Pali by Piyadassi Thera) [Online] Available from: https://www. accesstoinsight.org/tipitaka/sn/sn02/sn02.009.piya.html [Accessed: 21 ${ }^{\text {st }}$ September 2017].

Tipitaka- Samyutta Nikaya (1999b) Suriya Sutta: The Sun Deity's Prayer for Protection (SN 2.10) (trans. from Pali by Piyadassi Thera) [Online] Available from: https://www. accesstoinsight.org/tipitaka/sn/sn02/sn02.010.piya.html [Accessed: 21 ${ }^{\text {st }}$ September 2017].

UNESCO (2013) The Sacred Garden of Lumbini: Perceptions of Buddha's Birth Place, [Online] Available from: http://unesdoc. unesco.org/images/0022/002239/223986e.pdf [Accessed: $13^{\text {th }}$ December 2017].

Upadhayay, A. K. (1994) Janameiaya Inscription of 3014 B.C. [Online] Available from: https://www.scribd.com/ document/35948060/Janamejay-inscriptions [Accessed: 24 $4^{\text {th }}$ September 2017] pp: 1-3.

Vahial, M. N. \& Subbarayappa, B. V. (2011) Eclipses in Ancient India, Proceedings $4^{\text {th }}$ Symposium on History of Astronomy, Noajal, Japan, Jan 13-14, pp: 1-5.

Walshe, M. (1995) Long Distance Discourses of Buddha (Translation of Digha Nikaya), Boston: Wisdom Publications.

Walters, A. N. (1999) Ephemeral Event: English Broadsides of Early Eighteenth Century Solar Eclipses, History of Science, 37, pp: 1-43.

DOI: https://doi.org/10.1177/007327539903700101 